\title{
Critical Analysis of Javanese Epistemology and Its Relevance to Science Development in Indonesia
}

\author{
Reno Wikandaru'; Shely Cathrin'²; Erwinsyah Satria ${ }^{3}$; Dian Rianita ${ }^{4}$ \\ ${ }^{1}$ Faculty of Philosophy, Universitas Gadjah Mada, Indonesia \\ ${ }^{2}$ Jurusan Filsafat dan Sosiologi Pendidikan, Universitas Negeri Yogyakarta, Indonesia \\ ${ }^{3}$ PGSD Fakultas Keguruan dan Ilmu Pendidikan, Universitas Bung Hatta, Indonesia \\ ${ }^{4}$ Universitas Lancang Kuning Pekanbaru Riau, Indonesia \\ Corresponding Author: renowikandaru@ugm.ac.id
}

\begin{abstract}
Humans have developed science to understand the phenomena they face in their lives. As such, the development of science is inexorably linked with epistemology because it emphasizes the question of truth - the focus of epistemology. The development of science and knowledge has been influenced by specific interests, motives, needs, and historic/cultural backgrounds. To ensure that science is developed in a manner best suited for Indonesian society, such development must be rooted in extant Indonesian cultural values, such as those found in Javanese culture. This study attempts to formulate Javanese epistemology as a basis for scientific development in Indonesia. It finds, first, that knowledge is known as "kawruh" among the Javanese people; second, knowledge is not always limited to the cognitive dimension; and third, a specific criterion for truth is harmony, or "pener". Javanese people consider "rasa" capable of bringing humans to the supreme knowledge. Although objective knowledge exists, every individual achievement of reality is different. Javanese people consider the validity or truthfulness of statements/ actions rooted in their harmony with the empirical rational principle of truth and the existing order, following the adage "bener tur pener".
\end{abstract}

Keywords: epistemology; Indonesia; Javanese; philosophy; subjectivism

\section{INTRODUCTION}

Science and knowledge have been developed to allow humans to understand the phenomena in their lives. The goal of science development is simple: to ensure the correct explanation of various phenomenon in their lives and allow appropriate action for making improvements (Satria \& Widodo, 2020). This effort has been undertaken over hundreds of years, producing the various sciences that are known today. Throughout this time, science has given considerable emphasis to the problem of truth. As such, the development of science is linked to epistemology, which deals with "truth" as its central question.

Recognizing existing developments of science and knowledge to date, it cannot be denied that the
Western world has made many contributions to science. Beginning with the ancient Greek thinkers, empirical and rational science and knowledge have been developed dynamically as times have changed and human relations have intensified, ultimately spreading around the world. Given this background, it can be concluded that the development of science and knowledge has been influenced by the interests, motives, wants, and historic/ cultural backgrounds of specific actors. The development of science is thus inexorably linked to culture and society. Consequently, it is affected by cultural relativity, a condition through which a culture may be incomparable to other cultures. 
More explicitly, the science and knowledge developed in the West tends to be empirical and rational, as they are influenced by their Western developers' sociocultural background. These embedded Western cultural values, however, are not always congruent with the cultural values in other cultures. This has serious implication, as it means that Western science may not always be easily accepted by non-Western people. Consequently, there has been a call for the indigenization of science and knowledge, as proposed by - among others - the Indonesian philosopher Ignas Kleden in in his 1987 book Sikap Ilmiah dan Kritik Kebudayaan (The Scientific Attitude and Cultural Criticism) (Kleden, 1987).

The current study was motivated by the abovementioned demand for the indigenization of science. For science to better fit Indonesian society, its development must be rooted in existing Indonesian cultural values. This may include, for example, the cultural values held by the Javanese, an ethnic group in Indonesia that has been selected for discussion owing to its significant population. Various Javanese cultural artifacts and practices-recognized internationally as including wayang puppetry, gamelan music, and literary works such as Serat Centhini, Serat Wulang Reh, and Serat Wedhatama - embody much philosophical thinking, including epistemological approaches useful for the development of science in Indonesia. Unfortunately, there has been little systematic discussion of Javanese philosophy, particularly epistemology.

This study is intended to pioneer the systemization of Javanese philosophy, particularly in the field of epistemology. Its material object (or field of inquiry) is the Javanese community activities related to their understanding of knowledge. The formal object or scientific point of view used as an analytical tool is philosophy, more specifically epistemology or the philosophy of knowledge. Based on the character of the object, this research is best designed as field research using an anthropological-philosophical approach. However, given that anthropological data on Javanese culture is widely available in scientific publications, books, papers, and articles, this research has prioritized a library research approach. However, this is combined with several field research methods such as observations and interviews to obtain the latest and most accurate data. Data is analyzed using a combination of the descriptive method, historical method, language analytics method, hermeneutic method; and heuristic method, focusing on three areas of study: Javanese literary tradition; the pakeliran or wayang purwa tradition; and phrases commonly used in Javanese society.

\section{ELEMENTS OF JAVANESE EPISTEMOLOGY Elements of Javanese Epistemology in
Literature}

Javanese culture is rich with diverse traditions found across the expansive island of Java. Many Javanese cultural artifacts and practices are recognized; one of these is literature, works created as expressions of local wisdom in Javanese culture. This study uses two works of literature that are considered to represent the corpus of media expressing Javanese culture: Serat Wedhatama (Mangkunagoro IV, 1979) and Serat Wulang Reh (serat meaning 'book') (Darusuprapta, 1988). In other words, elements of Javanese epistemology in literary tradition are examined here by studying the epistemological thinking embedded within the serat.

\section{Epistemological Dimensions of Serat Wedhatama by Mangkunegara IV}

Serat Wedhatama is a serat written by K.G.P.A.A. Mangkunegara IV, born Raden Mas Soediro in 1809 (Javanese calendar: Legi Sunday, 1 Sapar, Jimakir 1736). In his youth, he joined the Mangkunagaran Legion as an infantry soldier. During this time, he fought various battles, including in Cirebon, Palembang, and Diponegaran (Sabdacarakatama, 2010). K.G.P.A.A. Mangkunegara IV was a leader with knowledge not only about politics and war strategies, but also about poetry. He wrote numerous literary works, mostly poems (tembang), which remain beloved by Indonesian (particularly Javanese) society. These include Tripama, Manuhara, Nayakawara, Yogatama, Pariminta, Pralambang, Lara Kenya, Pariwara, Rerepen, Prayangkara, Sendhon, Langenswara, and Wedhatama (Wikandaru, 2013).

The epistemological dimensions of Serat Wedhatama can be seen in several parts of the serat. One involves the role of rasa in the process of obtaining human knowledge. Serat Wedhatama implies that the key to gaining knowledge regarding God is the sensitivity of rasa or human intuition, as only through intuition can humans obtain knowledge of the innermost properties of the universe (Wikandaru, 2013). The knowledge (ngelmu) obtained through rasa is not knowledge as understood by modern people, based on assumptions and verifications of the power of the human mind and empiricism. Rather, ngelmu can be understood simultaneously as "knowledge", "meaning", and "magical power" (MagnisSuseno, 2001).

Another epistemological aspect of Serat 
Wedhatama refers to the properties of knowledge. As true knowledge is closer to batin (the mind) and can only be achieved through rasa, the properties of knowledge in Serat Wedhatama are very subjective, depending on humans' ability to interpret symbols. Each person may have a different level of knowledge regarding a topic, as each person exhibits different levels of rasa (Wikandaru, 2013). For the Javanese, true knowledge is 'supernatural' and subjective, an insight or personal view that cannot be formulated objectively (Mulder, 1985). Based on the above description of rasa, it can be concluded that Serat Wedhatama presents an intuitionist epistemological view of epistemology, which prioritizes intuition in obtaining human knowledge. Intuition refers to actions of higher knowledge, which are actually or assumed to approach the completeness of spiritual understanding (Bagus, 2000).

\section{Epistemological Dimensions of Serat Wulang Reh by Pakubuwana IV}

Another literary work filled with epistemological content is Serat Wulang Reh by Sri Susuhunan Pakubuwana IV (1768-1820), the sunan (ruler) of Surakarta Hadiningrat. Pakubuwana IV was a great poet who supported the survival of Javanese lifestyle, and was so known for his noble character and handsome appearance that he was nicknamed "Sinuhun Bagus". Serat Wulang Reh was completed on 19 Besar, Ahad Kliwon in year Dal, approximately twelve years before its author's death (Darusuprapta, 1988).

Serat Wulang Reh is a classical Javanese-language work in the form of a tembang macapat (sung poem). The language is simple, without difficult words (dakikdakik), and as such its content and intentions are readily understood by readers. The simple language in serat Wulang Reh helps in understanding the content in the lines of the tembang.

Serat Wulang Reh contains ethical lessons promoting ideal personal development. Initially, it was dedicated to the royal family and expected to guide them in their self-development. Later, it reached the public outside of the palace through abdi dalem (courtiers), thus allowing the text's teachings to benefit Javanese society and be applied at any time. The text, thus, can be seen as a guide to realizing one's obligations (Darusuprapta, 1988).

The concept of knowledge in Serat Wulang Reh is quite similar to that in Serat Wedhatama, but differs significantly from Western concepts. Its uniqueness is in its conceptual simplicity. The Javanese people strongly believe that sejatining Ngelmu kelakone kanthi laku, which is translated as: the essence of knowledge is its application. This line, which originates from Serat
Wedhatama, shows the way that Javanese people combine theory and practice. They understand knowledge not only as the cognitive content of human mind or awareness, but also as laku (action). Therefore, one cannot become wise simply by memorizing theories without practicing them. Wise people are those whose practice is supported by theoretical knowledge. A similar lesson is presented in Serat Wulang Reh.

When understanding Javanese culture, the concept of transcendence cannot be ignored (Dojosantoso, 1986). Humans are viewed as incomplete, as "microrealities". To achieve knowledge on sangkan-paran, on the beginning and end, on the alpha and omega, one must surpass and transcend oneself into the reality of jagad gedhe, the macro-cosmos. Javanese culture in general reflects a tension between immanence and will, with immanence being surpassed through transcendence.

Serat Wulang Reh shows that human immanence is a sign human weakness, as in the following line (Darusuprapta, 1988).

yen sira ayun waskitha/ sampurnane ing badanira puniki/sira anggugurua/

Translation: if you want to see clearly/perfect your body/you should study.

Understanding the Javanese people's concept of knowledge and its acquisition means understanding the structure of the subject's ontic reality and the prerequisites that exist within the subject to enable him to obtain knowledge. In the West, this is understood through Immanuel Kant's concept of the categorical imperative (Muthmainnah, 2018). Meanwhile, in the line quoted above, humans must first perfect their "badan wadag" (physical body) before obtaining knowledge. This can be viewed as an imperative prerequisite without which humans will fail to obtain knowledge. Before seeking perfection, humans must realize their own weakness.

Revelation is considered the main source of true knowledge. This also shows the concept of transcendence as understood by Javanese people and within the formal teachings of Islam. Since revelation is the source of true knowledge, the objectivity/validity of knowledge can be ascertained absolutely - this is, after all, a core characteristic of revelation. Here, we must abandon the prejudice of Western understandings of science as scientific knowledge and pseudoscience as pseudoknowledge, beliefs, and unscientific matters; otherwise, comprehending the Javanese understanding of knowledge as laku intended towards achieving perfection will fail. Religion, religiosity, and matters are considered 
faith or pseudoscience in the West are not viewed the same way in Java. Javanese people believe that, due to transcendentalism, true knowledge comes from God, sang hyang kang tan kena kinira.

Serat Wulang Reh remains popular among the Javanese people, who still heed its teachings in their daily practices. Moral and intellectual sharpness are the main characteristics conveyed through Serat Wulang Reh (Darusuprapta, 1988). Knowledge is obtained when human thought unites with action. The dualism of empiricism and idealism is thus solved, as for Javanese people the essence of knowledge lies not between these diametric poles, but in the unity of theory and practice, a vision of the ethical dimensions emphasized in Serat Wulang Reh. Knowledge is not obtained solely through the mind; people may cleverly cover their lies. The essence of knowledge is real application (Darusuprapta, 1988).

Serat Wulang Reh, thus, essentially explains that knowledge begins with applied knowledge. The focus of knowledge for the Javanese people is transcending immanent human weaknesses. Knowledge, thus, is used by humans and for their good.

Objectivity is considered in Western philosophy a requirement for valid theoretical knowledge, including argument consistency, logical deduction, internal systematization, and other standardization systems. Meanwhile, the Javanese people, as explained by Serat Wulang Reh, do not separate theoretical and practical knowledge. For them, the validity of knowledge rests on knowledge's application and ethical impact on human life. Objectivity, or the measurability of knowledge, rests not only on the internal dimensions of knowledge, but also external dimensions, framed as understandings of the ethical impacts of knowledge.

To close this discussion of Javanese epistemological elements in Serat Wulang Reh, we conclude that the main key to understanding the essence of knowledge according to Javanese people is sejatining ngelmu kelakone kanthi laku, freely translated as meaning that knowledge is not solely the theoretical dimension of human cognition, but also behavioral dimensions. In other words, knowledge is the unification of theory and practice. It is necessary to improve one's behaviors when seeking true knowledge through science.

Epistemologically, the main source of knowledge in Serat Wulang Reh is revelation (as understood in Islamic teachings) as well as teachers' guidance. As the source of knowledge is revelation, Javanese epistemology cannot use the Western categories of science and pseudo-science. For the Javanese people, knowledge is a human endeavor to reach perfection and overcome all immanent weaknesses attached to their bodies. Learning, therefore, is transcendence, born from tension between the awareness of immanent weaknesses and the drive for perfection.

According to Serat Wulang Reh, the objectivity of knowledge is not limited solely to internal dimensions of knowledge, but is also found in its external dimension. The practical application of knowledge determines whether knowledge is useful. In Serat Wulang Reh, objectivity - understood as an intrinsic condition for knowledge to be scientific and correct-is shifted to the ethical-applicative dimension. The text focuses on the basic question of how knowledge helps people achieve perfection as jagad cilik (micro-verses) and discover his position in the jagad gedhe (macro-verse).

\section{Epistemological Elements in Wayang Purwa}

One art form that remains popular among the Javanese people is wayang purwa, an old Javanese art. In Pustaka Raja Purwa, it is stated that shadow puppet shows once used simple equipment, but this has been transformed into puppets made of buffalo hide carved by tatah, using kelir (screens), blencong (lighting), kepyak (k.o. musical instrument), etc. Wayang is certainly an indigenous Javanese art, as it has existed since before Hinduism entered Java (Tedjowirawan, 2014).

Wayang, as a Javanese (and Indonesian) cultural heritage is very interesting from a philosophical point of view. Wayang stories are replete with character education, presenting ideal life as understood ancestrally. Many carangan characters and plays are meant to connect philosophical concepts in wayang with actual practices in audiences' lives. However, the knowledge aspect of wayang is often not understood by audiences, who only speculate, leading to a shift in meaning. Therefore, the epistemological aspects of wayang should be investigated to understand clearly the knowledge presented, as well as the characteristics and validity of that knowledge.

First, we examine the understanding of wayang of the source of knowledge. Before we discuss the search for knowledge through wayang, it should be noted that studying wayang philosophically requires a hermeneutical analysis. Hermeneutics serve to interpret texts and scientifically describe their meaning. Before Indonesian independence, wayang shows were held in the pringgitan part of the pendapa of Javanese houses. Audiences watched the show from behind the screen, only seeing the shadows of the puppets as cast by light from 
the blencong. Today, the position of wayang audience has changed; audiences watch from behind the dalang (puppeteer), looking directly at the wayang. This is clearly a contemporary phenomenon that need not discard noemena (reality) (Sutrisno et al., 2009).

Epistemological investigation into wayang performances shows that classical shows, where people watched shadows on the screen, were more imaginative. This is congruent with Plato's analogy; as shadows on cave walls are not the knowledge and truth of reality, the shadows of wayang as shown by the dalang are not reality. Audiences who watched from the pendapa, guests who were respectfully invited to sit in the pendapa, could coherently understand the meaning of the shows and stories played comprehensively and integrally behind the puppets' movements. However, in reality most contemporary audiences fail to catch this meaning owing to the exposure of the shows, which today are predominantly intended to provide entertainment. Audiences', thus, become akin to the slaves of Plato's cave, only capable of enjoying the shadows on the wall. Guidance and teachings are the reality intended to be shown to audiences by the dalang. These can only be learned when audiences remove their sensory desires and remove themselves from the modern logical mind, the logics of time; in other words, modern logic (Sutrisno et al., 2009).

In his article "Upaya Awal ke Arah Perumusan Filsafat Wayang" ("An Early Effort to Formulate the Philosophy of Wayang'), Solichin describes a slave who is released from his restraints in a cave, but becomes confused and dazzled by the firelight and sunlight outside; he argues that wayang audiences experience the same thing (Solichin, 2001). They are confused and dazzled by the inevitable perception of truth, which comes from the idea of goodness (likened to a platonic sun). Human capacity and competence must become accustomed to this "platonic brightness" to reach noesis. Logic should be moved to intellectus and intuition, accessing the kawruh (understanding or knowledge) of wayang through their hearts and senses. Only then will audiences understand the meaning of wayang shows as a form of traditional knowledge, one that is sensible, combined with wisdom and even perfection in the true reality or kasunyatan.

Kasunyatan is part of truth, but kasunyatan in wayang it is at least equal to goodness as the supreme idea. First, in the Javanese traditional culture that contains the teachings of wayang, truth seems to be substituted with kabecikan, as seen, for example, in the line bener nanging ora pener; ngelmu kang nyata maweh reseping ati; ngono ya ngono nanging aja ngono, with everything referring to an ethical category. Secondly, if truth is the highest value in kawruh, how is it different from modern science? Third, as traditional knowledge, kawruh does not exclude the basic properties of traditions whose epistemic reality contains synoptic segments (form, knowledge, and happiness). In Javanese culture, knowledge of reality requires both intellect and tuition, as 'knowledge' is understood as meaning more than what is known (Sutrisno et al., 2009).

Next, we identify the properties of knowledge as shown in wayang. To do so, an axiological study on subjective, objective, and inter-subjective values should be used. Values - properties or qualities that make something valuable, worth having or wanting, admired, respected, upheld, and desired — guide humans' lives. Objectivity and subjectivity are related to everything inside and outside of human mind. In this definition, objectivity is everything measurable through the human mind or through human perceptions. Subjectivity, meanwhile, takes the forms of perception, beliefs, and feelings. Objective views tend to be value-free, while subjective views are not. Both have their strengths and weaknesses. In the tradition of knowledge, objectivity produces quantitative knowledge, while subjectivity produces qualitative knowledge.

For example, a 2.5 meter tall cupboard can be measured, and its height is an objective fact. However, perceptions of the cupboard vary. For example, some may consider the cupboard ugly, mediocre, or good. The value produced by objective research produced a single truth, which collapses if any different results are obtained, while subjective research tends to be plural and contextual. Objectivism is based on the actual situation, while subjectivism is based on an opinion that something exists because it is considered to exist.

A value is objective if it does not depend on a subject or the awareness of an appraiser. Meanwhile, it is subjective if its existence, meaning, and validity depends of the reaction (psychological or physical) of an appraising subject (Frondizi, 2001). Inter-subjective meaning, meanwhile, emerges from the intersection of 'social' and 'action'. Conceptually, 'social' refers to the relations between two or more people, while 'action' is defined as behaviors with subjective meanings. However, intersubjective meaning does not emerge within the private world of an individual, but interpreted in conjunction with one or more other individual. Subjective meanings, thus, become inter-subjective through its aspects of similarity and togetherness.

Related to the study of the philosophy of wayang is its applicative side. The epistemological focus will lead to understanding the Javanese (and, by 
extension, Indonesian) thinking cultures as contextual. For comparison, Western modern culture positions science as the thinking culture. This implies that, for modernization to be successful, a community must change its thinking culture to accept scientific thinking. Here, the modernization of Javanese culture may be viewed as is unnecessary, with the continued acculturation of the basic philosophy inherent in Javanese culture being preferable (Sutrisno et al., 2009).

Based on the above descriptions of subjective, objective, and inter-subjective values, it may be concluded that the knowledge in wayang performances is inter-subjective. This is shown in the story Dewaruci, in which Bima seeks tirtha amerta (sacred water) to achieve perfection. His search the filled with mythical stories, reinforcing the assumption that the story is based on the Javanese thinking culture. To comprehend the meaning of Dewaruci, thus, observers are advised to understand the mindset of the Javanese people.

\section{Javanese Epistemological Elements of Common Phrases in Javanese Society}

Studying the epistemological elements of common phrases in Javanese society is not easy, considering that, as a culture, the Javanese people use hundreds and even thousands of common phrases to express their philosophy or life wisdom. Muhammad A. Syuropati, for example, has collected Javanese adages in his book Kumpulan Mutiara Kearifan Jawa: 800+ Mutiara Jawa Terpopuler ('A Collection of Javanese Pearls of Wisdom: 800+ of the Most Popular Javanese Sayings', 2015). Syuropati collected over 800 Javanese proverbs, adages, or unenunen related to knowledge, society, family life, etc. Owing to space constraints, discussion of the epistemological elements in common Javanese will not include all of the sayings in the book. Here, we will only discuss several adages or unen-unen related to the Javanese people's views of knowledge.

One famous phrase in Javanese society is a quote from Serat Wedhatama: "ngelmu iku kalakone kanthi laku". According to Syuropati, this means that knowledge should be applied through action and involve strong intention as well as efforts to control desires (Syuropati, 2015). Implicitly, this quote implies that knowledge (ngelmu) gains meaning when it is implemented through action. It reemphasizes the literary elements of Javanese epistemology above: the Javanese people consider knowledge to be closely related to human action. In other words, a wise person's actions will show his wisdom and virtues.
Another phrase popular among Javanese people, which is also related to epistemology, is "bener nanging ora pener", which is sometimes connected to another phrase, "ngono yo ngono nanging aja ngono". According to Javanese-Indonesian dictionaries, the word bener means "correct", as does the word "pener". This produces the seemingly oxymoronic translation "correct but incorrect".

The Javanese people are known for their rich adages, which frequently confuse people of other heritages - as seen in the example above. In the case of "bener nanging ora pener", an understanding of the semantic differences between bener and pener is necessary. Although both words are translated as "correct", the semantic implications of bener differ from those of pener. Bener connotes a truth related to logic, rationality, thinking, etc., while "pener" connotes truth in a "way" or "means". As such, the phrase bener nanging ora pener is better translated "the facts may be correct, but delivered through an incorrect means".

This is very interesting for the current article, as epistemological discussions generally focus on one category of correct. Javanese people, however, have different traditions of viewing truth, recognizing two categories: the substance of a statement and its delivery. Both aspects must be realized, though - quite interestingly - using the correct means is weighted more heavily than providing correct information. Statements that are bener but not pener are of little use. It is insufficient for a statement to be bener, as correct facts must be delivered in a correct manner (pener).

This brief description of Javanese epistemological elements in common phrases in the society is far from comprehensive. However, from the phrases discussed above, it can be concluded that knowledge is traditionally related to human behavior in Javanese society. Factual correctness is not, in and of itself, sufficient to indicate knowledge; knowledge should also be pener, correctly delivered to others and applied in life.

\section{THE ESSENCE OF JAVANESE EPISTEMOLOGY}

As described above, epistemology is a branch of philosophy that specifically discusses knowledge. Many points of view are used by philosophers to explain how epistemology studies the essence of knowledge. One simple point of view is proposed by Titus, et al. (1984), who identify three main problems in epistemology:

1. The character of knowledge;

2. the source of knowledge; and 
3. the correctness of knowledge.

This discussion of Javanese epistemology departs from the epistemological categories formulated by Titus et al. (Titus et al., 1984). It examines four main questions that became the basis for formulating Javanese epistemology: first, the essence of knowledge; second, the source of knowledge; third, the character of knowledge; and fourth, the validity of knowledge.

\section{THE ESSENCE OF KNOWLEDGE}

The question of the essence of knowledge is central in epistemological study, occupying a fundamental and determinative position in the field. As a philosophical study that specializes in understanding knowledge and knowing, epistemology first seeks the essence of knowledge. It asks: what is knowledge? Does knowledge automatically contain truth? What is truth?

Exploring the essence of knowledge as understood by the Javanese people means asking these questions to Javanese people. In practice, it means looking for answers to these questions in the Javanese epistemological elements discussed above. Related to the first question, regarding the meaning of knowledge, the Javanese people term knowledge "kawruh". This meaning can be found in nearly all cultural elements in Javanese society. One of the most concrete examples is found in wayang.

Wayang kulit purwa is an ancient art form that has survived even today, in the midst of relentless cultural development. As discussed above, multiple elements of Javanese epistemology are apparent in wayang, including kawruh. One lakon (story) particularly rich in kawruh is Dewaruci. This study will not examine the story in detail. Here, the author only describes the understanding of kawruh found in the pakeliran tradition or wayang.

One point is that kawruh, as knowledge, is also known among the Javanese people as ngelmu. This term is also mentioned in Serat Wedhatama, specifically in the Pocung pupuh (canto), which reads ngelmu iku, kalakone kanthi laku; this line has already been discussed above, in the context of Javanese epistemological elements in literatures. The term kawruh, though sometimes equated or considered synonymous with the Indonesianlanguage term pengetahuan or the English-language term knowledge, has a deeper meaning. For laypeople, or perhaps persons who view knowledge through the paradigm of Western science, the formula one plus one equals two $(1+1=2)$ can be termed knowledge. Kawruh, as understood by the Javanese people, is not so simple. Franz Magnis-Suseno writes kawruh implies more than knowing. It is an event that changes humans, that gives new dimensions and depths to their existence, provides a new reality (Magnis-Suseno, 2001). Knowledge, thus, is understood by the Javanese people as involving not only cognitive aspects, but also affective (attitude) and psychomotor (behavior) aspects. One who receives kawruh will experience attitude and behavioral changes; one who receives kawruh regarding goodness, for instance, will become more oriented towards goodness. Javanese epistemology, thus, considers knowledge as congruent with virtue. This is one of the most fundamental distinctions between the Western understanding of knowledge and the Javanese people's understanding of kawruh. Knowledge, as understood through the Western paradigm, is associated predominantly with cognition or intelligence, essentially boiling down to human rationality. Meanwhile, for the Javanese, kawruh is associated predominantly with attitudes and behaviors, and thus has a practical dimension. Kawruh significantly influences Javanese people, and is closely related to how knowledge is obtained.

The Javanese people view knowledge - kawruh, or ngelmu - as not being obtained simply, such as through schooling. As implied through the adage ngelmu iku kalakone kanthi laku, a process is required for obtaining knowledge. This process, or laku, does not only have cognitive dimensions, but also affective and psychomotor dimensions. Serat Wedhatama states that, to achieve knowledge, one must cegah dhahar lawan guling or eat and sleep less. This kind of laku is termed prihatin or "ngrasakake perihing batin" (feeling the pain of the heart) by Javanese people. Only by making the mind accustomed to feeling pain will one achieve kawruh or knowledge. The level of knowledge attained, according to the Javanese epistemology, is influenced by the weight of one's laku prihatin. In other words, the Javanese people recognize several levels of kawruh or understanding.

In an interview, Achmad Charris Zubair, the Chairman of the Cultural Council of Yogyakarta, stated that the Javanese people recognize specific a concept of truth. When considering truth, the Javanese people do not use the word mikir ('thinking with the mind'), but menggalih, literally 'thinking with the heart'. This means that truth, in the Javanese epistemology, is not only related to rationality (the mind), but also to the heart. Based on the heart's role in considering the truth, Zubair suggested that the Javanese people recognize three levels of understanding, from lowest to highest: pinter, lantip, and waskitha. People who are pinter are skilled with calculations; people who are lantip have creative skills; and people who are waskitha are identified as ngerti sak durunge winarah (possessing knowledge before others 
give it to them). Knowledge that is only based on the mind (logic) will, according to the Javanese epistemology, only make people pinter, not lantip or waskitha. To become waskitha, the sensitivity of one's rasa must be increased through frequent use of the heart in considerations. This understanding contributes to the above-discussed concepts of laku, tirakat, and prihatin.

To close our discussion of the essence of knowledge, we reach three conclusions: first, knowledge is called kawruh by Javanese people; second, knowledge has more than cognitive dimension; and third, that the criteria of truth is in harmony or correct means (pener).

\section{SOURCE OF KNOWLEDGE}

The next epistemological problem pertains to the source of knowledge recognized by the Javanese people. The source of knowledge has been the subject of frequent epistemological discussion from philosophers throughout the ages. Several schools are recognized by Western thinking, two of the most prominent being rationalism and empiricism. Rationalism is a philosophical approach that emphasizes common sense or rationality as the primary source of knowledge, one that is superior to, and free/ independent from, sensory observation (Bagus, 2000). Conversely, empiricism is the doctrine that all knowledge is sourced from experience (Bagus, 2002). These two schools have frequently conflicted throughout the history of epistemology, and each has figures who have passed or preserved its views to the next generation of thinkers.

If, in the West, knowledge is seen as coming from rationality or experience, what is considered the source of knowledge by Javanese people? Do they follow empiricism, rationalism, or neither? The answer to this question can be found in the Javanese people's view or conception of humanity. Humans, as understood by the Javanese people, are generally understood as consisting of two elements, i.e. badan wadag and badan alus. Badan wadag means 'crude body' and refers to material constituent elements, while badan alus means 'fine body' and refers to non-material constituent elements. Humans' badan wadag can be seen in their physical appearance. One of the most important epistemological instruments, and part of this badan wadag, are the five senses-in other words, empiricism. Meanwhile, the human mind and rationality are considered elements of the badan alus.

Returning to the above epistemological debate between rationalism and empiricism, it can be concluded that the debate on the essential source of knowledge above comes from difference perspectives on the most essential elements of humanity. Rationalism considers the mind or rationality to be most essential for knowledge production, emphasizing the badan alus, while empiricism considers the senses the main factor in knowledge production, emphasizing the badan wadag. What, then, is the solution for this debate? Immanuel Kant, several centuries ago, attempted to stop the debate between rationalism and empiricism by proposing that both rationality and senses have important roles in creating knowledge.

The Javanese people also have a view on rationality and empiricism. They are very open, however, recognizing both the role of the mind and the role of the body in knowledge acquisition. However, they have a different view of which instrument is the most essential. Before describing this view, it should be noted that in epistemological study, the most important instrument of knowledge is determined by the subject's perspective on the world he faces. Is this world solely sensory, or are there any non-sensory elements contributing to its formation? The answer to this question has very broad and fundamental consequences.

Based on this point, we note that, to determine which knowledge instrument is relied on most by the Javanese people in obtaining knowledge, one must first learn their view of the world. The Javanese worldview has been discussed beautifully and comprehensively by Franz Magnis-Suseno, who states that the Javanese understand the world as more than empirical. Behind the empirical world, there is a meta-empirical (behind the physical) world. This meta-empirical world is the 'real reality', the deepest essence of the world. As such, it is impossible to expect empiricism or senses to lead to true knowledge. In other words, for the Javanese people, empiricism cannot bring people to the real truth. What about the mind? Can reason lead people to the real truth? Referring to the above-discussed typology of levels of knowledge, i.e. pinter, lantip, and waskitha, it appears that, for the Javanese people, rationality can only bring one to the pinter stage. To become lantip or waskitha, another epistemological instrument is necessary. The Javanese people call this instrument rasa.

Rasa, as a Javanese epistemological instrument, is similar to what is frequently termed intuitionism - a school that tends to prioritize intuition in obtaining human knowledge - in epistemological discussion (Wikandaru et al., 2018). This intuition is not that generally understood by laypeople, but rather higher actions that are actually or assumed to approach the completeness of spiritual understanding (Bagus, 2000). The Javanese people consider this intuition the only instrument capable of delivering true knowledge or real truth. To develop one's rasa and sensitivity in hopes of attaining this true 
knowledge or real truth, one must take many steps. These steps are termed laku or prihatin by the Javanese people, and commonly referenced in literary works such as Serat Wedhatama.

Rasa, as understood by the Javanese people, is an inherent ability that plays a large role in various aspects of Javanese life. Rasa, in social interaction, presents itself as tolerance. In the struggle with the self, rasa also informs the making of important life decisions. It has an even larger role in karawitan, as stated by Trustho, a lecturer at the Department of Karawitan of the Indonesian Institute of Arts, Yogyakarta; when a poet writes a gendhing (song) and plays it with a gamelan orchestra, rasa has an important role. The presence of rasa in social interaction determines comfort levels within said socialization.

This rasa, thus, answers the epistemological question of Javanese people's understanding of the source of knowledge. From the description above, it can be concluded that the Javanese people recognize humans as consisting of badan wadag and badan alus (i.e. physical and non-physical aspects). Humans' physical aspects are their senses, while their non-physical aspects are their minds and hearts or rasa. Among these epistemological aspects, according to Javanese tradition, only rasa can deliver the highest or truest knowledge.

\section{CHARACTER OF KNOWLEDGE}

The third problem discussed here is the property or character of knowledge in Javanese epistemology. Is knowledge objective, subjective, or inter-subjective? Objective knowledge is knowledge whose truth is accepted equally by everyone, while subjective knowledge is knowledge whose truth may differ between individuals. Inter-subjective knowledge, meanwhile, is knowledge whose truth may be the same among certain people.

In epistemological studies, the character of knowledge is closely related to the source of knowledge. When a culture bases its knowledge on an epistemological instrument that is held equally by everyone, it is very possible that the knowledge produced is objective. Conversely, if a culture bases its knowledge on an epistemological instrument whose condition differs between subjects, it is very possible that the knowledge produced is subjective or inter-subjective.

Previously, it was mentioned that the Javanese people recognize an objective reality. To reach this objective reality, the main source of knowledge is rasa, a sense of intuition that everyone possesses in different levels of sensitivity (Mulder, 1985). As with rationality or common sense, rasa provides humans with spiritual potential that gives them an advantage over other creatures. However, it often conflicts with rationality or common sense. Although rationality provides a means to understand everyday phenomena, Javanese people consider it as unable to capture the essence of said phenomena; this essence can only be found through rasa (Mulder, 1985). As each person has a different level of sensitivity, some can achieve this objective knowledge, while others, lacking sufficient sensitivity, cannot. One respondent, Dr. Sri Suryati Sutardjo, said that in wayang stories such as Dewaruci, Bima is an example of a person capable of attaining objective knowledge - in this case, knowledge of sangkan and paran or the origin and meaning of life. This knowledge is considered objective by the Javanese people.

To achieve objective knowledge, one must train one's rasa through various laku prihatin that are essentially intended to remove obstacles to the achievement of knowledge. As each person has a different ability to train the rasa, the level of knowledge that can be achieved by each person differs. Some can reach the level of lantip or even waskitha, while others may only reach the level of pinter. Among the Javanese, knowledge appears subjective, meaning that the essence of knowledge captured by each person is different owing to each person's distinct capacity for rasa.

Thus is knowledge characterized within the Javanese epistemology; for the Javanese people, although objective reality exists, each person has a different ability to understand it, and thus any knowledge attained is more subjective.

\section{VALIDITY OF KNOWLEDGE}

The fourth and final problem of Javanese epistemology discussed here is the validity of knowledge. The validity of knowledge refers to the criteria, measures, or basis used to determine that the knowledge achieved by humans is correct. In other words, it asks: what criteria are used to say that this knowledge is correct?

The problem of the validity of knowledge is frequently discussed in epistemological studies. Generally, every school of epistemology has its own view of validity. Empiricism, for example, argues that the measure of the validity of knowledge is when wellunderstood knowledge is viewed the same way by others. For example, the statement "That car is black" is considered the truth when others also see the car as being black. Rationalism has its own criteria regarding the validity of knowledge. A statement is considered to contain the truth when it makes sense and can readily be 
understood by every person. How, then, is the validity of knowledge measured among the Javanese people?

Based on an interview with Achmad Charris Zubair, one common phrase that can be used to determine the measure of the validity of knowledge as understood in Javanese society is "bener lan pener". This phrase shows that there are two ways to measure the validity of knowledge: bener and pener. Bener relates to the empirical and rational aspects of a statement. A statement is bener when it makes sense to others and is accepted by others' empirical understanding. In other words, when the truth of a statement can be proven empirically and rationally, it is considered bener by the Javanese.

The Javanese people also recognize another criterion for measuring the truth of a statement: pener. Pener is related to the extent to which a statement or action affects harmony in society. As widely recognized, Javanese society upholds harmony-individual, social, or cosmic (i.e. with nature) - in every aspect. This plays a central role in the Javanese understanding, including epistemology. When harmony is the measure of truth, the correctness of an action or statement is determined by the extent to which it influences harmony in the society. If an action meets the bener criteria but negatively affects the existing harmony, it is not considered pener. Ideally, an action must be based on the existing empirical/ rational truth (bener) without detrimentally affecting the existing harmony, be it individual or social (pener). This is the essence of the Javanese epistemological view of the validity of knowledge. In short, the Javanese people measure the (in)validity of a statement or action by its congruence with the existing empirical/ rational truth as well as support for the existing harmony.

\section{CONCLUSION}

Based on this study, several conclusions have been drawn regarding the essence of knowledge as understood by the Javanese people. First, knowledge is termed kawruh by the Javanese people; second, that knowledge is not always limited to cognitive dimension; and third, harmony (pener) is considered a criterion for truth. The Javanese people recognize humans as consisting of badan wadag and badan alus, i.e. as having both physical and nonphysical aspects. Physical aspects refer to the senses, while non-physical aspects refer to the mind and heart ( $r a s a)$. According to the Javanese people, of these aspects rasa or human intuition is most capable of bringing humans to the highest or truest knowledge. Although the Javanese people consider objective knowledge to exist, they see every individual achievement of reality as different; as such, any human knowledge is inherently subjective. Meanwhile, Javanese people measure the (in)validity of statements or actions by their congruence with existing empirical rational principles and the existing harmony, as represented through the adage bener lan pener.

\section{REFERENCES}

Bagus, L. (2000). Kamus Filsafat. Gramedia Pustaka Utama. Darusuprapta. (1988). Serat Wulang Reh anggitan dalem Sri Pakubuwana IV. Citra Jaya Murti.

Dojosantoso. (1986). Unsur Religius dalam Sastra Jawa. Aneka Ilmu.

Frondizi, R. (2001). Pengantar Filsafat Nilai (Diterjemah). Pustaka Pelajar.

Kleden, I. (1987). Sikap Ilmiah dan Kritik Kebudayaan. LP3ES.

Magnis-Suseno, F. (2001). Etika Jawa: Sebuah Analisa Falsafi tentang Kebijaksanaan Hidup Jawa. Gramedia Pustaka Utama.

Mangkunagoro IV, K. G. P. A. (1979). Wedhatama (Terjemahan). Pradnya Paramita.

Mulder, N. (1985). Pribadi dan Masyarakat di Jawa: Penjelajahan Mengenai Hubungannya, Yogyakarta, 1970-1980. Pustaka Sinar Harapan.

Muthmainnah, L. (2018). Tinjauan Kritis Terhadap Epistemologi Immanuel Kant (1724-1804). Jurnal Filsafat WISDOM, 28(1), 74-91.

Sabdacarakatama, K. (2010). Serat Wedhatama: Karya Sastra K.G.P.A.A. Mangkunegoro IV. Narasi.

Satria, E., \& Widodo, A. (2020). View of teachers and students understanding' of the nature of science at elementary schools in Padang city Indonesia. Journal of Physics: Conference Series, 1567, 32066. https:// doi.org/10.1088/1742-6596/1567/3/032066

Solichin. (2001). Upaya Awal ke Arah Perumusan Filsafat Wayang.

Sulistyo, E. T. (2015). The Implicature of Tembang Gambuh in Serat Wedhatama and Its Significance for the Society. Humaniora, 27(1), 96-106. https://doi. org/10.22146/jh.6413

Sutrisno, S., Siswanto, J., Ariani, I., Hadiprayitno, K., Wilda, M., \& Purwadi. (2009). Filsafat Wayang. Sena Wangi.

Syuropati, M. A. (2015). Kumpulan Mutiara Kearifan Jawa. Syura Media Utama.

Tedjowirawan, A. (2014). Serat Pustakaraja Purwa: Serat Darmasarana Karya Pujangga R.Ng. Ranggawarsita Di Abad XIX: Analisis Struktur-Resepsi-Genealogi. Universitas Gadjah Mada.

Titus, H. H., Smith, M. S., \& Nolan, R. (1984). PersoalanPersoalan Filsafat (Terjemahan). Bulan Bintang.

Wikandaru, R. (2013). Dimensi Epistemologis Serat 
Humaniora, Vol. 32, No. 3 (October 2020)

Wedhatama: Relevansinya Bagi Pengembangan Ilmu di Indonesia.

Wikandaru, R., Lasiyo, L., \& Sayuti, S. A. (2018). Rasa Sebagai Prinsip Pertama Ontologi Harmoni dalam Pathet Pergelaran Wayang. Wawasan: Jurnal Ilmiah Agama Dan Sosial Budaya. https://doi.org/10.15575/ jw.v3i2.5629 